\title{
Motility and Viability of Spermatozoa of Belgian Blue Crossbreeds with the Addition of Tomato (Solanum lycopersicum) Extract in Egg Yolk Citrate Diluent
}

\author{
Sigit Bintara ${ }^{1, *}$, Panjono Panjono ${ }^{2}$, and Riyan Nugroho Aji ${ }^{1}$ \\ ${ }^{1}$ Department of Animal Breeding and Reproduction, Faculty of Animal Science, Universitas Gadjah Mada, \\ Yogyakarta, Indonesia \\ ${ }^{2}$ Department of Animal Production, Faculty of Animal Science, Universitas Gadjah Mada, Yogyakarta, Indonesia \\ ${ }^{*}$ Corresponding author. Email: sigitbintara@ugm.ac.id
}

\begin{abstract}
Crosses between local cattle and pure Belgian Blue cattle often causes birth difficulty because the calf size is too large. In order to avoid this problem, crossbreeding is not conducted with pure Belgian Blue cattle, but with Belgian Blue crossbreeds. In order to support the crossbreeding program between local cattle and Belgian Blue Crossbreeds, it is necessary to study the semen quality of Belgian Blue crossbreeds. This study was aimed to determine the effect of adding tomato (Solanum lycopersicum) extract to egg yolk citrate diluent on the motility of liquid semen and the viability of spermatozoa in Belgian Blue Crossbreed cattle stored at $5^{\circ} \mathrm{C}$. Semen was collected from a 3-year-old Belgian Blue Crossbreed, using an artificial vagina. Semen examination was carried out at the Animal Physiology and Reproduction Laboratory, Universitas Gadjah Mada. The treatments in this study consisted of egg yolk citrate diluent (Control), egg yolk citrate diluent and $4 \%$ of tomato extract (P1), egg yolk citrate diluent and $6 \%$ of tomato extract (P2), and egg yolk citrate diluent and $8 \%$ of tomato extract (P3). Data obtained from microscopic examination were analyzed using analysis of variance based on Completely Randomized Design (CRD). The results showed that the addition of tomato extract could improve maintaining $(\mathrm{P}<0.05)$ motility and viability of spermatozoa stored at $5^{\circ} \mathrm{C}$ for 96 hours. Semen motility at $\mathrm{P} 0, \mathrm{P} 1, \mathrm{P} 2$, and $\mathrm{P} 3$ were $36.8 \%, 42.5 \%, 41.3 \%$ and $46.8 \%$, respectively. The viability of spermatozoa at P0, P1, P2, and P3 was $61.3 \%, 68.5 \%, 69.3 \%$ and $74.3 \%$, respectively. The addition of $8 \%$ of tomato extract presented the best results in maintaining motility (46.8\%) and viability of spermatozoa (74.3\%) after 96 hours. The conclusion of this study was that the addition of $8 \%$ of tomato extract into egg yolk citrate diluent could improve the quality of liquid semen, which included motility and viability of spermatozoa.
\end{abstract}

Keywords: Belgian Blue Crossbreeds; Motility; Spermatozoa; Tomato extract; Viability.

\section{INTRODUCTION}

Crosses between local cattle and pure Belgian Blue cattle often causes birth difficulty because the calf size is too large. In order to avoid this problem, crossbreeding is not conducted with pure Belgian Blue cattle, but with Belgian Blue crossbreeds. In order to support the crossbreeding program between local cattle and Belgian Blue Crossbreeds, it is necessary to study the semen quality of Belgian Blue crossbreeds, especially the motility and viability of the spermatozoa. Optimization of the management of Belgian Blue (BB) cattle includes the need for efficient [1] methods of semen storage, due to the fertility capacity and semen motility of fresh semen in vitro usually decrease within an hour after collection
[2]. Artificial insemination (AI) is a powerful and unique technique for increasing reproductive efficiency, AI needs fresh or well preserve semen which be preserved in formulate dilution to maintain the quality of spermatozoa in it [3], [4]. Furthermore, it is necessary to find and evaluate semen diluent used to preserve during chilling or cryopreservation [5]. The use of nature dilution has been widely carried out including using the extract tomatoes [6]. Lycopene as a carotenoid found in tomatoes has been considered in preset studies as an antioxidant to prolong life span of bull semen which undergo the chilling and cryopreservation process [7], though did not obtain yet the motility rate or viability in BB cattle. This antioxidant was effective in protecting cell destruction from $\mathrm{NO}_{2}$-radical compounds [8], also 
neutralize the adverse effects of free radicals. Egg yolk citrate diluent was also reported had a good quality [9], [10]. This study was aimed to determine the effect of adding tomato (Solanum lycopersicum) extract to egg yolk citrate diluent on the motility of liquid semen and the viability of spermatozoa in Belgian Blue Crossbreed cattle stored at $5^{\circ} \mathrm{C}$.

\section{MATERIAL AND METHOD}

\subsection{Animals and chemicals}

A three years old of Belgian Blue bull was maintained under standard field laboratory condition and performed in accordance with the University guidelines. Diluent liquid egg yolk citrate (2:8), tomatoes extract, eosin, liquid nitrogen, and distilled water. Tomatoes extract made by mixed dried tomatoes which diluted in $96 \%$ ethanol.

\subsection{Semen collection and initial evaluation}

Semen was collected using an artificial vagina and initially evaluated for semen quality. Semen have normal color, $>80 \%$ motility and viability and 3,080 \pm 130.21 $10 \% \mathrm{~mL}$ concentration, $<10 \%$ abnormality.

\subsection{Post Chilled Semen evaluation}

To avoid individual effect, the semen ejaculates were pooled. After that, semen was diluted with egg yolkcitrate (1:4). The diluted samples were split into four aliquots according to tomatoes extract (P0: control; P1: 4\%; P2: $6 \%$ and P3: 8\%). The samples were kept in a cold cabinet for period $96 \mathrm{~h}$ at $5^{\circ} \mathrm{C}$ and monitored for semen motility and semen viability. The semen motility were determined by homogenized $10 \mu \mathrm{L}$ diluent, mixed with $\mathrm{NaCl}$ (1:4), and then observed using microscope (Olympus $\mathrm{CH} 20$ ) with a magnification $100 \times 400$. The scores of microscope observation were given in the range $0-100 \%$ with a $5 \%$ scale [11]. Procedure of eosin staining was applied to investigate semen viability. For each sample, a total of 200 spermatozoa were counted and observed using light microscope (Olympus CH 20). This procedure was aimed to investigate the reacted and nonreacted spermatozoa. The death spermatozoa with damaged acrosome emitted the strong red color whereas non-reacted with were live spermatozoa emitted with light pink or no color.

\subsection{Statistical analyzed}

All the experiment results were expressed as mean \pm standard deviation (SD). Completely Randomized Design (CRD) was used to determine the significant between the mean value, followed by Duncan post hoc test with $p<0.05$ as the statistically significant criterion.

\section{RESULT AND DISCUSSION}

Semen color and volume from the Belgian Blue were observed $(n=3)$. The fresh semen color were normal, the semen motility was $87 \pm 1.00 \%$, viability was $90 \pm 1.2 \%$. These findings were similar with previous study[12] and suitable to the next cryopreservation process. Semen analysis quality included semen concentration, semen motility, and semen viability. This quality was determined to support the fruitfulness of AI program[13]. Cooling preservation was reduced the quality of diluent semen which happened in this study that the motility and viability were significantly $(p<0.05)$ decreased during the chilling process (Table 1) due to the cold shock leads the alteration of membrane structures permeability, which similar with previous study [14].

The result of adding tomato extract on the motility and viability of refrigerator $\mathrm{BB}$ bull semen were presented in Table 1. Supplementation of tomato extract in semen diluent were significantly $(p<0.05)$ increased the motility and viability on bull semen (Table 1), rather than the control treatment. The result was shown that addition extract tomatoes to the semen egg yolk citrate diluent significantly promoting motility and viability by against the damage effect from spermatozoa metabolism, such us ROS or another free radical metabolites [15]. Tomato extract which rich in lycopene might played on ROS breakdown abilities and protective agents to against oxidative damage to spermatozoa cell [16].

Table 1. Effect of Tomatoes extract addition in semen extender on Belgian Blue bull semen motility and viability stored at $5^{\circ} \mathrm{C}$ for $96 \mathrm{~h}$

\begin{tabular}{|l|l|l|l|l|}
\hline \multirow{2}{*}{ Tomato extract } & \multicolumn{2}{|l|}{ Motility (\%) } & \multicolumn{2}{l|}{ Viability (\%) } \\
\cline { 2 - 4 } & $0 \mathrm{~h}$ & $96 \mathrm{~h}$ & $0 \mathrm{~h}$ & $96 \mathrm{~h}$ \\
\hline Control & $81.00 \pm 1.60^{\mathrm{a}}$ & $36.90 \pm 0.80^{\mathrm{Ab}}$ & $81.60 \pm 1,10^{\mathrm{a}}$ & $61.30 \pm 0.80^{\mathrm{Ab}}$ \\
\hline $4 \%$ & $82.80 \pm 2.20^{\mathrm{a}}$ & $42.50 \pm 0.50^{\mathrm{Bb}}$ & $86,60 \pm 1.10^{\mathrm{a}}$ & $68.50 \pm 0.50^{\mathrm{Bb}}$ \\
\hline $6 \%$ & $82.60 \pm 1.10^{\mathrm{a}}$ & $41.30 \pm 0.70^{\mathrm{Cb}}$ & $86.80 \pm 0,80^{\mathrm{a}}$ & $69.30 \pm 1.00^{\mathrm{Cb}}$ \\
\hline $8 \%$ & $83.20 \pm 0.40^{\mathrm{a}}$ & $46.80 \pm 0.80^{\mathrm{Db}}$ & $87.20 \pm 0.80^{\mathrm{a}}$ & $74.30 \pm 1.60^{\mathrm{Db}}$ \\
\hline
\end{tabular}

${ }_{\mathrm{ABCD}}$ Means in a row not sharing superscript show significant differences $(\mathrm{p}<0.05)$ for tomatoes extract addition. ${ }^{a b c}$ Means in a column not sharing superscript show significant differences $(p<0.05)$ during storage time for 96 hours at $5^{\circ} \mathrm{C}$. 
Carotenoid, the particularly lycopene had reported ploy as on scavengers of singlet oxygen and other free radicals such as ROS by donated numerous electrons so could neutralize ROS [7]. Lycopene on tomato extract was able to snare ROS before that's radicals could embark oxidative chain reaction[17]. Effectivity ROStrapped on lycopene determined via the total antioxidant capacity or activity of prominent antioxidant enzymes[18]. Lycopene supplementation could prevent peroxidative damage to spermatozoa lipid compared to the control group [16], [19]. Based the result study, the supplementation tomato extract concentration in $8 \%$ in diluent semen shown the highest motility and viability bull spermatozoa. This result could be happened due to the antioxidant on $8 \%$ concentration restores the equilibrium between the amounts of ROS produced and rummaged which in turn could maintain the sperm metabolic rate [20]. Despite the lower concentration did not found the equilibrium point between the antioxidant and free radicals and made the motility of sperm was decreased. The excessive ROS concentration was leading to superoxide formation and attacked plasma membrane cell which rich in PUFA, when the PUFA were damage, this condition would lead the increased permeability of sperm plasma membrane, enzyme inactivation and structural membrane damage to spermatic DNA and caused degradation of sperm motility, viability and membrane integrity [21]. The results shown that the post chilled motility and viability on treatment semen could maintain in minimum allowed level for frozen and chilled semen commercial based on SNI which minimum Chilled-Viability above $40 \%$, whereas the control semen was the decline semen due to the chilled under $40 \%$ [22].

\section{CONCLUSION}

Based on the current studies, it was summarized the addition of tomato extract affects the quality of Belgian Blue bull spermatozoa after cooling. The best results of membrane motility and integrity were obtained at the tomato extract concentration on $8 \%$ compared with the others treatment.

\section{ACKNOWLEDGMENTS}

The author would thanks the Faculty of Deputy for Strengthening Research and Development, Ministry of Research and Technology/National Research and Innovation Agency, PT Widodo Makmur Perkasa, PT Pasir Tengah, and Bengkel Sapi Kalijeruk Yogyakarta for partially sponsoring the research.

\section{REFERENCES}

[1] Purwantara, B., O. Parlindungan, Y. Siswanti, M. Imron, and Y. Setiawan. 2018. Oral Presentation (FA-8) Embryo Transfer and Artificial Insemination Program of Belgian Blue Cattle in
Indonesia: Pregnancy Rate, Birth Weight and Calving Ease. Hemera Zoa. 147: 69-71

[2] Bustani, G. S., and F. H. Baiee. 2021. Semen extenders: An evaluative overview of preservative mechanisms of semen and semen extenders. Vet. World. 14(5):1220-1233.

[3] Raheja, N., S. Choudhary, S. Grewal, N. Sharma, and N. Kumar. 2018. A review on semen extenders and additives used in cattle and buffalo bull semen preservation. J. Entomol. Zool. Stud. 6(3):239-245.

[4] Aviles, C. H., C. C. Love, R. Serafini, L. R. Agamez, M. Friedrich, S. Ghosh, S. R. Teague, A, K. Lacaze, S. P. Brinsko, D. D. Varner. 2020. Effects of glucose concentration in semen extender and storage temperature on stallion sperm quality following long-term cooled storage. Theriogenology. 147:1-9.

[5] Santos, M., F. Soares, M. Moreira, and J. Beirão. 2018. Evaluation of different extenders for the cold storage of meagre (Argyrosomus regius) semen. Aquac. Res. 49(8):2723-2731.

[6] Muhammad, M.,K. Eriani, A. Fithri, A. Rusdi, and H. Saputra. 2020. Potential of Flamboyant Flower (Delonix regia (Boj. ex Hook) Raf) Extract to Maintain Post-Dilution Quality of Aceh Cattle (Bos taurus indicus) Spermatozoa. E3S Web Conf.151: 1-5.

[7] Mangiagalli, M. G., V. Cesari, S. Cerolini, F. Luzi, and I. Toschi. 2012. Effect of lycopene supplementation on semen quality and reproductive performance in rabbit. World Rabbit Sci. 20(3):141-148.

[8] Al-Daraji, H. J., I. A. A. Hassan, A. S. Ahmed, R. H. Razuki. 2006. Improving sperm characteristics during in vitro storage of roosters ' semen by supplementing semen diluent with tomato juice. The Iraqi Journal of Agricultural Sciences, 37(4):165-171.

[9] Hoesni, F. 2016. Pengaruh penggunaan Tris dalam pengencer susu skim terhadap resistensi spermatozoa sapi simmental pasca pembekuan. J. ilmu-ilmu Peternak, 19(2): 77-82.

[10] Kurnia, A., S. Soeparna, R. I. Arifiantini, and R. Hidayat. 2018. Fertilitas Semen Beku dalam Tris Kuning Telur dan Skim yang Diberi Omega-3 pada Sapi Simmental dengan Ransum Berimbuhan Seng dan Selenium Minimal. J. Vet., 19(2): 251-262.

[11] Priyanto, L., R. I. Arifiantini, T. L. Yusuf. 2015. Deteksi Kerusakan DNA Spermatozoa Semen 
Segar dan Semen Beku Sapi Menggunakan Pewarnaan Toluidine Blue. J. Vet. 16(1):48-55.

[12] Morrell, J. M., A. S. Valeanu, N. Lundeheim, and A. Johannisson. 2018. Sperm quality in frozen beef and dairy bull semen. Acta Vet. Scand., 60(1)1-10.

[13] Herbowo, M. T., R. I. Arifiantini, N. W. K. Karja, and R. G. Sianturi. 2019. Cryopreservation of swamp buffalo semen in skim milk yolk-based diluent with two different cryoprotectants. Trop. Anim. Sci. J, 42(1)13-18.

[14] Sieme, H., H. Oldenhof, and W. F. Wolkers. 2015. Sperm Membrane Behaviour during Cooling and Cryopreservation. Reprod. Domest. Anim., 50:20-26.

[15] Bucak, M. N., P. B. Tuncer, S. Sariozkan, N. Baspinar, M. Taspinar, K. Coyan, A. Bilgili, P. P. Akalin, S. Buyukleblebici, A. Aydos, S. Ilgaz, A. Sunguroglu, D. Oztuna. 2010. Effects of antioxidants on post-thawed bovine sperm and oxidative stress parameters: Antioxidants protect DNA integrity against cryodamage. Cryobiology. 61(3):248-253.

[16] Tvrda, E. Z. Knazicka, and N. Lukac. 2012. Selected heavy metals versus antioxidant parameters in bull seminal plasma - A comparative study. J. Environ. Sci. Heal. - Part A Toxic/Hazardous Subst. Environ. Eng., 47(9):1261-1266.

[17] Esguerra, J. P. M., J. M. U. P. H. Quimio, G. A. Dichoso, C. A. L. Junsay, V. A. Magpantay, and P. P. Sange. 2020. Coconut water with either tomato juice or garlic extract as extender components for Paraoakan native chicken semen at different storage temperatures. Philipp. J. Sci., 149 (1):121-131.

[18] Türk, G., A. Ateşşahin, M. Sönmez, A. Yüce, and A. O. Çeribaşi. 2007. Lycopene protects against cyclosporine A-induced testicular toxicity in rats. Theriogenology, 67(4):778-785.

[19] Stojević, Z., N. Filipović, P. Božić, Z. Tuček, and J. Daud. 2008. The metabolic profile of Simmental service bulls. Hrcak, 78(2):123-129.

[20] J Len, J. S., W. S. D. Koh, and S. X. Tan. 2019. The roles of reactive oxygen species and antioxidants in cryopreservation. Biosci. Rep. 39(8): $1-25$.

[21] de Jong, A. M. E., R. Menkveld, J. W. Lens, S. E. Nienhuis, and J.P. T. Rhemrev. 2014. Effect of alcohol intake and cigarette smoking on sperm parameters and pregnancy. Andrologia. 46(2):112-117.
[22] Sianturi, R. G., B. Purwantara, B., I. Suprianta, P. Situmorang. 1998. Pengaruh glutation dan penggantioan plasma semen kerbau dengan semen sapi terhadap kualitas semen beku kerbau rawa. JITV, 18(3): 143-148. 